\title{
Stability of encapsulated and non-encapsulated anthocyanin in yogurt produced with natural dye obtained from Solanum melongena L. bark
}

Flavia Jamille de Figueiredo Paes Barretto ${ }^{1}$, Heleni Aires Clemente ${ }^{2}$,

Andrea Lopes Bandeira Delmiro Santana ${ }^{3}$, Margarida Angélica da Silva Vasconcelo ${ }^{4}$

\begin{abstract}
This research evaluated the stability of non-encapsulated and spray-dried encapsulated anthocyanin from Solanum melongena L. bark as a natural dye in yogurts. Anthocyanin was extracted using $70 \%$ cereal alcohol acidified with citric acid at $\mathrm{pH}$ 2.0. Extract spray-drying was defined using the experimental design $\left(2^{2}\right)$, with drying temperature $\left({ }^{\circ} \mathrm{C}\right.$ ) and carrier concentration (Gum arabic) as independent variables. The response variable adopted was the total monomeric anthocyanin content. The following analyses were performed: color; total monomeric anthocyanins; total phenolic contents; antioxidant activity using the DPPH• (1,1-diphenyl-2-picrylhydrazyl) radical; $\mathrm{pH}$; and acidity. Yogurt degradation constant, half-life, and color retention percentage of anthocyanin added to

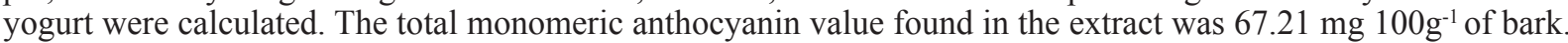
Natural non-encapsulated and encapsulated dye extract were added to yogurt at concentrations of $1.0 ; 1.5$; and $2 \mathrm{~g}$ extract $/ 100 \mathrm{~mL}$ yogurt. Average $\mathrm{pH}$ values after addition of anthocyanin extract ranged from 3.60 to 3.87 . Acidity was $1.04 \%$ in natural yogurt (time zero), while $1 \% ; 1.5 \%$; and $2 \%$ samples showed $1.4 ; 1.7$; and $2.05 \%$ and 1.18 ; 1.29 ; and $1.47 \%$ acidity in non-encapsulated extract added to yogurt and encapsulated extract added to yogurt, respectively. Anthocyanin content decreased during storage using non-encapsulated extract, remaining constant in encapsulated extract added to yogurt. The three formulations showed increased L* at thirty days, with discoloration being related to decreased anthocyanin content. DPPH• radical scavenging activity decreased during the 30 days

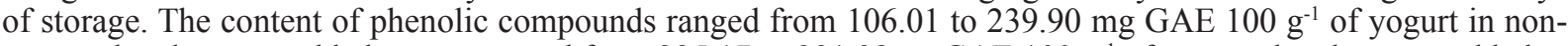

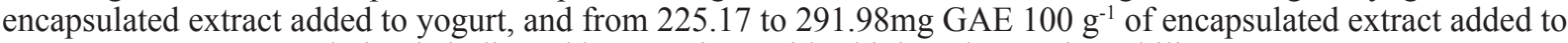
yogurt. Extract encapsulation is indicated because it provides high anthocyanin stability.
\end{abstract}

Index terms: Anthocyanidins, dye, spray-drying, dairy products, eggplant.

\section{Avaliação da estabilidade das antocianinas em iogurte elaborado com corante natural obtido da casca de Solanum melongena $\mathrm{L}$. encapsulado e não encapsulado}

Corresponding author: fjamille@hotmail.com

Received:September05, 2019 Accepted:April 20, 2020

Copyright: All the contents of this journal, except where otherwise noted, is licensed under a Creative Commons Attribution License.

(cc) $\mathrm{EY}$

\begin{abstract}
Resumo - Esta pesquisa teve como objetivo avaliar a estabilidade das antocianinas da casca de Solanum melongena L., encapsuladas pelo processo de secagem em spray dryer e não encapsuladas como corante natural em iogurtes. A extração de antocianinas foi realizada utilizando álcool de cereais a $70 \%$, acidificado com ácido cítrico a $\mathrm{pH}$ 2.0. A secagem do extrato por atomização foi definida utilizando o delineamento experimental $2^{2}$, tendo como variáveis independentes a temperatura de secagem e a concentração do agente carreador (goma arábica). A variável de resposta adotada foi o teor de antocianinas monoméricas. Foram realizadas as seguintes análises: cor, antocianinas monoméricas, fenólicos totais, determinação da atividade antioxidante, utilizando o radical DPPH•, $\mathrm{pH}$ e acidez. Foram calculados a constante de degradação, o tempo de meia-vida e a porcentagem de retenção de cor das antocianinas adicionadas ao iogurte. Para as antocianinas monoméricas, o valor encontrado no extrato foi de

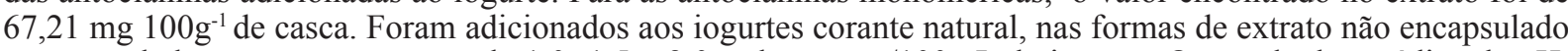
e encapsulado, nas concentrações de 1,$0 ; 1,5$ e 2,0 g de extrato/100mL de iogurte. Os resultados médios de $\mathrm{pH}$, após a adição do extrato de antocianinas no iogurte, variaram entre 3,60 e 3,87. O parâmetro de acidez para tempo zero no iogurte natural foi de $1,04 \%$, enquanto as amostras de $1 \% ; 1,5 \%$ e $2 \%$ foram de 1,$4 ; 1,7$ e $2,05 \%$ e 1,18 ; 1,29 e 1,47\% para o iogurte adicionado do extrato não encapsulado, e o iogurte adicionado de extrato encapsulado respectivamente. A respeito de medições feitas no iogurte adicionado do extrato não encapsulado e encapsulado, verificou-se maior redução no teor de antocianinas no iogurte adicionado do extrato não encapsulado durante o armazenamento, enquanto no iogurte adicionado de extrato encapsulado o teor de antocianinas se manteve constante. Considerando os dias 0 e 30 da avaliação da cor nas três formulações, houve aumento em L*, mostrando descoloração, que está relacionada à redução do teor de antocianinas. A capacidade de sequestro do radical $\mathrm{DPPH}^{\circ}$ diminuiu durante os 30 dias de armazenamento. As quantidades de compostos fenólicos variaram entre 106,01 e 239,90 mg

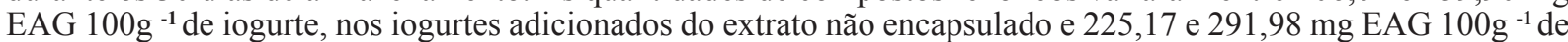
iogurte, nos iogurtes adicionados de extrato encapsulado. O encapsulamento dos extratos é indicado, pois garantiu maior estabilidade das antocianinas.
\end{abstract}

Termos para indexação: Antocianidinas, corante, atomização, produtos lácteos, berinjela. 


\section{Introduction}

The substitution of artificial dyes for natural dyes is among the main concerns of the food industry, since natural pigments have gained the attention of researchers and consumers due to their safety, nutritional properties and biological activity. Most of these natural pigments are health-promoting ingredients because they have shown preventive effects against various diseases. Anthocyanins, for example, can have beneficial health effects due to their antioxidant, anti-inflammatory, anti-cancer and antidiabetic properties, being therefore of great interest to the food industry (RODRIGUEZ-AMAYA, 2016).

Eggplant (Solanum melongena L.) is native to eastern and southeastern Asia and has spread around the world from India. It is represented by Solanum macrocarpon L. and S. aethiopicum L. species, grown mainly in Africa and by $S$. melongena species, grown in other countries (TAHER et al., 2017; KNAPP et al., 2013). In Brazil, eggplants are known as dark fruits, purple in color, with small shade variations (dark wine color, shiny black). The external fruit color is due to the presence of anthocyanin-type flavonoids (TEIXEIRA et al., 2008; TADARO et al., 2009; NISHA et al., 2009; JUNG et al., 2011). Nasunin, the main flavonoid of eggplant, is an anthocyanin-type flavonoid heteroside derived from delfinidine (aglycone). Nasunin provides the eggplant skin intense purple color (NODA et al., 2000).

Flavonoids are phenolic compounds belonging to a group of substances widely distributed in the plant kingdom. These compounds are potent free radical scavengers, donating hydrogen, and their high antioxidant potential is related to their large number of phenolic hydroxyls. Fruits are the main dietary sources of polyphenols; however, the composition of these constituents in these foods is diversified according to variety, cultivar, edaphoclimatic conditions, among others (SILVA et al, 2012; KOBUS-CISOWSKA et al, 2020).

Teixeira, Stringheta and Oliveira (2008) compared the method for quantification of anthocyanins, single $\mathrm{pH}$ and differential $\mathrm{pH}$, and found 64.06 and $56.75 \mathrm{mg} 100 \mathrm{~g}^{-1}$ of sample, respectively, for eggplant, using ethanol-water as solvent (70:30) acidified with $\mathrm{HCl}$ to $\mathrm{pH} 2$. The use of single $\mathrm{pH}$ is a faster method, but false result can be obtained if there is presence of interferents such as sugars, so it was decided to use differential $\mathrm{pH}$ to carry out the present study.

Anthocyanins have low stability due to sensitivity and changes in $\mathrm{pH}$, temperature, light, oxygen, among other factors, which is the main limitation for the use of these pigments as potential substitutes for artificial dyes in foods. However, the stability of these bioactive compounds can be markedly improved with encapsulation, allowing their properties to remain unchanged for longer periods of time (MUHAMAD et al., 2018; OTÁLORA et al, 2019).

Anthocyanins can potentially be used as additive, not only as dyes, due to their antioxidant properties and stability under acidic conditions (MUHAMAD et al., 2018). Thus, the use of anthocyanins as additive for yogurts, which are acidic and stored under refrigeration, can add nutraceutical value to yogurts, as well as to eggplant.

In this context, dairy by-products added of anthocyanins are an alternative for the food industry to develop products with better nutritional quality and with less environmental impact. In view of the above, this work aims to evaluate the stability of anthocyanins obtained from Solanum melongena L. bark encapsulated by spray drying and not encapsulated as natural dye in yogurts.

\section{Material and methods}

\section{Fruit}

Solanum melongena $\mathrm{L}$. fruits were purchased at local stores in the city of Recife-PE at the ripe stage, defined by the purple color of their bark. To obtain the bark, fruits were sanitized with sodium hypochlorite, according to manufacturer's recommendation for 15 minutes, allowed to dry at room temperature, peeled with stainless steel knife and submitted to anthocyanin extraction.

\section{Lactic Bacteria}

Lyophilized lactic Yolac ${ }^{\circledR}$ Y70A5U cultures containing Lactobacillus delbrueckii ssp. bulgaricus and Streptococcus salivarius ssp. Thermophilus were acquired in the city of Natal-RN.

\section{Obtaining the anthocyanin extract from Solanum melongena $\mathrm{L}$ bark}

Anthocyanin extract was obtained from $S$. melongena bark $(5 \mathrm{~g})$ by contact. The size of bark particles was $\pm 2 \mathrm{~cm}$, using $70 \mathrm{~mL}$ of hydrated cereal alcohol (corn, rice) and $30 \mathrm{~mL}$ of water acidified with citric acid at $\mathrm{pH} 2$, for 48 hours, without stirring at temperature of $5^{\circ} \mathrm{C}$ and absence of light (SILVA et al, 2010). The solution was filtered to separate the solid fraction and concentrated under vacuum at temperature of $38^{\circ} \mathrm{C}$ up to $15 \%$ of the initial volume. The anthocyanin extract was packed in dark bottles and stored $\left(-18^{\circ} \mathrm{C}\right)$ for later application in yogurt and drying. The initial monomeric anthocyanin content, antioxidant activity and total phenolic content in the extract were quantified. 


\section{Spray drying}

Part of the extract was submitted to spray drying using gum arabic as carrier agent at concentrations ranging from 10 to $20 \%$ (Table 1). For drying on laboratory scale, mini spray dryer - Lab Maq ${ }^{\circledR}$, model MSDi 1.0, was used, which operates with liquid flow of $0.2-1.0 \mathrm{~L} / \mathrm{h}$, nozzle of $1.2 \mathrm{~mm}$ in diameter, air flow of $30 \mathrm{~m}^{3} / \mathrm{h}$ and air pressure of 0.6 bar. Average flow rate of $0.84 \mathrm{~L} / \mathrm{h}$ was used.

\section{Experimental design}

Experimental design $\left(2^{2}\right)$ was carried out with drying temperature $\left({ }^{\circ} \mathrm{C}\right)$ and gum arabic concentration as independent variables and the total monomeric anthocyanin content as response variable. Based on results, the best condition was applied to yogurt using completely randomized design (CRD).

\section{Yogurt elaboration}

UHT milk was added of granulated sugar in an amount of $10 \%$ of the milk volume and $5 \%$ of powdered milk to increase the amount of solids. The mixture was heated to $42^{\circ} \mathrm{C}$ and then $2 \%$ lactic yeast was added using Lactobacillus delbrueckii ssp. bulgaricus and Streptococcus salivarius ssp. thermophilus commercial culture (Yolac ${ }^{\circledR}$ Y70A5U); after this stage, incubation was carried out until reaching $\mathrm{pH} 4.5-4.7\left(43-45^{\circ} \mathrm{C}\right)$. Subsequently, the yogurt was cooled to $4^{\circ} \mathrm{C}\left( \pm 1^{\circ} \mathrm{C}\right)$ and then homogenized and added with natural dye extracted from Solanum melongena L. bark in the form of nonencapsulated and encapsulated extract at concentrations of $1.0,1.5$ and $2 \mathrm{~g}$ of extract / $100 \mathrm{~mL}$ of yogurt.

\section{Yogurt Stability}

\section{Storage}

Products were placed in $100 \mathrm{ml}$ glass bottles protected from light and stored for a period of 30 days at $4^{\circ} \mathrm{C}$ in the absence of light. During this period, formulations were evaluated on the first day and every 10 days, with three samples being collected from each treatment to check color, concentration of monomeric anthocyanins, antioxidant activity, total phenolic compounds, $\mathrm{pH}$ and acidity.

\section{Colorimetric analysis}

The objective evaluation of the color of yogurts was carried out by means of colorimetry in the CIELAB $\operatorname{system}\left(\mathrm{L}^{*} \mathrm{a} * \mathrm{~b} *\right)$, using colorimeter (Konica Minolta ${ }^{\circledR}$ ), performing reading on the $\mathrm{L}^{*}$ axis (luminosity), which varies from black (0) to white (100); on the a * axis, from green $(-a)$ to red $(+a)$ and on the $b *$ axis, from blue $(-b)$ to yellow $(+b)$.

\section{Titratable acidity (TA) and pH}

Titratable acidity and $\mathrm{pH}$ were determined according to methodology described by AOAC (2005).

\section{Extraction of anthocyanins from yogurt}

For the extraction of anthocyanins from yogurt, $20 \mathrm{~g}$ of yogurt sample were mixed with $20 \mathrm{~mL}$ of $20 \%$ trichloroacetic acid in water. After shaking for 30 seconds, samples were incubated in heating bath at $42^{\circ} \mathrm{C}$ for 10 minutes and then centrifuged at 3500rpm for 15 minutes with supernatant being directly used in analyses (ZULUETA et al., 2009). Filtered extracts were used to determine monomeric anthocyanins, antioxidant activity and total phenolic contents.

\section{Monomeric anthocyanins}

The anthocyanin content was determined by the differential $\mathrm{pH}$ method described by Giust \& Wrolstad (2001).

To determine the anthocyanin content in the encapsulated extract, $0.05 \mathrm{~g}$ of sample were weighed and directly diluted in $\mathrm{pH} 1$ and $\mathrm{pH} 4.5$ solutions $(20 \mathrm{~mL})$, placed under stirring on a magnetic stirrer for 20 minutes, filtered and left to stand protected from light at room temperature $\left(25 \pm 1^{\circ} \mathrm{C}\right)$. At the end of 20 minutes, absorbance was recorded at $520 \mathrm{~nm}$ and $700 \mathrm{~nm}$ in spectrophotometer (Shimadzu ${ }^{\circledR}$ UV-1650PC) (RIGON and NOREÑA, 2016).

\section{Determination of the antioxidant activity DPPH method • (1,1-diphenyl-2-picrylhydrazyl)} Extracts obtained were used to evaluate the capacity to scavenger the 1,1-diphenyl-2-picrylhydrazyl (DPPH •) radical according to method described by Brand-Williams, Cuvelier, Berset (1995), with modifications. Aliquots of $0.2 \mathrm{~mL}$ of each extract were transferred to test tubes containing $3.8 \mathrm{~mL}$ of DPPH - solution in methanol $(0.1$ $\mathrm{mM})$. After slight agitation, tubes were left to stand protected from the light at room temperature $\left(25 \pm 1^{\circ} \mathrm{C}\right)$ and at the end of 60 minutes, absorbance was recorded at $515 \mathrm{~nm}$ in spectrophotometer (Shimadzu ${ }^{\circledR}$ UV-1650PC). Methanol was used to reset the spectrophotometer and a solution containing $0.2 \mathrm{ml}$ of methanol and $3.8 \mathrm{ml}$ of $\mathrm{DPPH} \cdot$ was used as blank.

\section{Determination of the total phenolic compounds}

The content of phenolic compounds of extracts was determined by spectrophotometry using Folin-Ciocalteu (Merk $\left.{ }^{\circledR}\right)$ reagent and gallic acid as reference standard (WETTASINGHE \& SHAHIDI, 1999). Results were expressed in mg of total phenolic compounds in gallic acid equivalent (GAE) per 100g of bark. 


\section{Anthocyanin degradation kinetics}

First-order kinetic model was used to describe anthocyanin degradation during the storage of yogurts. The degradation constant (k) (equation 1), the halflife time $\left(\mathrm{t}_{1 / 2}\right)$, defined as the time in which half of the anthocyanin content degrades (equation 2), and the color retention percentage (equation 3 ) were determined according to methodology described by Wallace \& Giusti, (2008) and Katsaboxakis et al. (1998).

$$
\begin{aligned}
& A_{t}=A_{0} \times \exp (-k \times t) \\
& t_{1 / 2}=\ln (2) / k \\
& \% \text { Retention }=A_{t} / A_{0} \times 100
\end{aligned}
$$

Where $\mathrm{k}=$ reaction constant, $\mathrm{t}=$ time $(\mathrm{h}), \mathrm{A}_{\mathrm{t}}=$ final anthocyanins $\mathrm{A}_{0}=$ initial anthocyanins, $\mathrm{t}_{1 / 2}=$ half-life time.

For $A_{t}$ in the non-encapsulated extract, anthocyanin reference value at 20 days of storage was considered.

\section{Statistical treatment}

All determinations were performed in triplicate and the averages of values found were submitted to Analysis of Variance (ANOVA) and Tukey's Test at 5\% probability level using the "Statistica" statistical software (Statsoft inc $\left.{ }^{\circledR} 7.0\right)$.

Table 1. Responses obtained from spray drying of Solanum melongena L. bark extract.

\begin{tabular}{cccc}
\hline Test & Temperature $\left({ }^{\circ} \mathrm{C}\right)$ & Gum Arabic & $\begin{array}{c}\text { Anthocyanin } \\
\left(\mathrm{mg} / 100 \mathrm{~g}^{-1} \text { bark }\right)\end{array}$ \\
\hline 1 & $(-1) 130$ & $(-1) 10$ & 18.43 \\
2 & $(+1) 180$ & $(-1) 10$ & 21.11 \\
3 & $(-1) 130$ & $(+1) 20$ & 15.76 \\
4 & $(+1) 180$ & $(+1) 20$ & 5.81 \\
5 & $(0) 150$ & (0) 15 & 40.48 \\
6 & $(0) 150$ & (0) 15 & 42.61 \\
7 & $(0) 150$ & (0) 15 & 40.14 \\
8 & $(0) 150$ & (0) 15 & 39.81 \\
\hline
\end{tabular}

\section{Results and discussion}

\section{Extraction}

The monomeric anthocyanin content determined in the Solanum melongena L. bark extract was 67.21 mg $100 \mathrm{~g}^{-1}$ bark. Tadaro et al. (2009) determined the monomeric anthocyanin content of eggplant bark extracted with different extracting solvents and found values close to

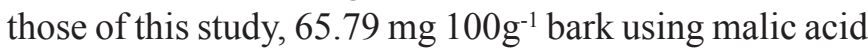

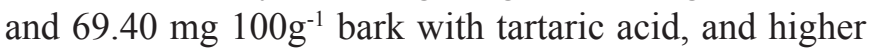
with extraction in $70 \%$ ethanol acidified with $1 \% \mathrm{HCL}$,

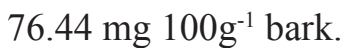

\section{Spray drying}

Results obtained for the drying of Solanum melongena L. extract are shown in Table 1, with the best condition for preserving anthocyanins drying at temperature of $150^{\circ} \mathrm{C}$ and $15 \%$ gum arabic (condition observed in the central point of the planning), maintaining average anthocyanin content of $64 \%$. According to the Pareto diagram (Figure 1), corresponding to the effects of independent variables in the drying process, it was shown that gum arabic concentration and temperature had negative influence on the anthocyanin content, both individually and in combination. It was found that the intermediate values for parameters under analysis are the most indicated. Bernstein and Noreña (2015) also obtained better response using $15 \%$ of carrier agent at temperature of $140^{\circ} \mathrm{C}$ when encapsulating red cabbage anthocyanins. 


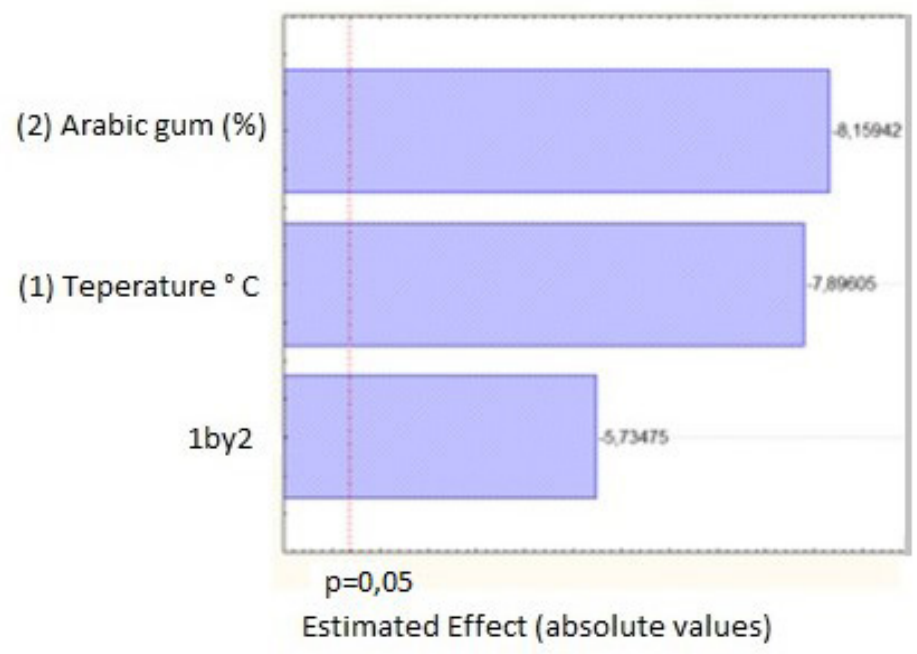

Figure 1. Pareto's Diagram

Characterization of non-encapsulated and encapsulated Solanum melongena $\mathrm{L}$. bark extract

Data on the initial concentrations of phenolic compounds and antioxidant activity in the non-encapsulated
Solanum melongena L. bark extract after spray drying are shown in table 2.

Table 2. Characterization of non-encapsulated and encapsulated Solanum melongena L. bark extracts

\begin{tabular}{ccc}
\hline Analyses & Non-encapsulated extract & Encapsulated extract \\
\hline $\begin{array}{c}\text { Total phenolic compounds } \\
\left(\mathrm{mg} \mathrm{GAE} 100 \mathrm{~g}^{1}\right)\end{array}$ & $487.50^{\mathrm{a}}$ & $460.87^{\mathrm{a}}$ \\
\hline $\begin{array}{c}\text { DPPH antioxidant activity }(\%) \\
\text { at } 60 \text { minutes }\end{array}$ & $91.68^{\mathrm{a}}$ & $91.25^{\mathrm{a}}$ \\
\hline
\end{tabular}

Means in rows followed by the same letters do not differ statistically from each other using the Tukey test ( $>>0.05)$.

Phenolic compounds in eggplant are identified as the main bioactive compounds responsible for their antioxidant effects (KAUR et al., 2014). Total phenolic compounds in non-encapsulated Solanum melongena L. extract were evaluated by the Folin Ciocalteau method and results were $487.50 \mathrm{mg}$ GAE $100 \mathrm{~g}^{-1}$ (gallic acid equivalent) and $460.87 \mathrm{mg} \mathrm{GAE} 100 \mathrm{~g}^{-1}$ (gallic acid equivalent) for encapsulated extract, showing similar results before and after drying. Rezende et al (2018) evaluated the phenolic content in the extract and after encapsulation of acerola extract and also found similar values before and after drying.

Results in the extract were higher than those reported by Nisha et al. (2009), whose values ranged from

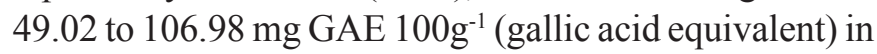
the methanolic extract in four different eggplant varieties, and lower than those found by Jung et al . (2011) in 70\%

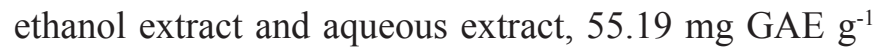
and $54.94 \mathrm{mg} \mathrm{GAE} \mathrm{g}^{-1}$ fresh eggplant bark, respectively.
Environmental conditions and physiological factors can modify the amounts of phytochemicals present in vegetables. The amount of phenolic compounds present in eggplants is significantly influenced by genotype, type of environment, soil and growth, as well as by cultivation and grafting systems (NIÑO-MEDIDA et al 2017).

Different solvent systems have been used to extract polyphenols from plant material. There is great variation in the extract composition depending on the solvent system used. The phenolic content and consequently the antioxidant activity of natural extracts depend on the solvent used for extraction (KOBUS-CISOWSKA et al, 2020).

The interest in evaluating the antioxidant capacity is the result of several studies on the importance of antioxidants in biological systems. The capacity of nonencapsulated and encapsulated Solanum melongena L bark extract to scavenge the DPPH $\bullet$ radical, shown in Table 2, demonstrated that there was no significant difference in antioxidant activity before and after the drying process. 


\section{Physicochemical quality of yogurts}

The average results for $\mathrm{pH}$ after the addition of nonencapsulated anthocyanin extract in the yogurt presented in Figures 2 and 3 showed significant differences among the three formulations at zero time and natural yogurt, all of which were between 3.60 and 3.87, while the natural yogurt $\mathrm{pH}$ was 4.57 .

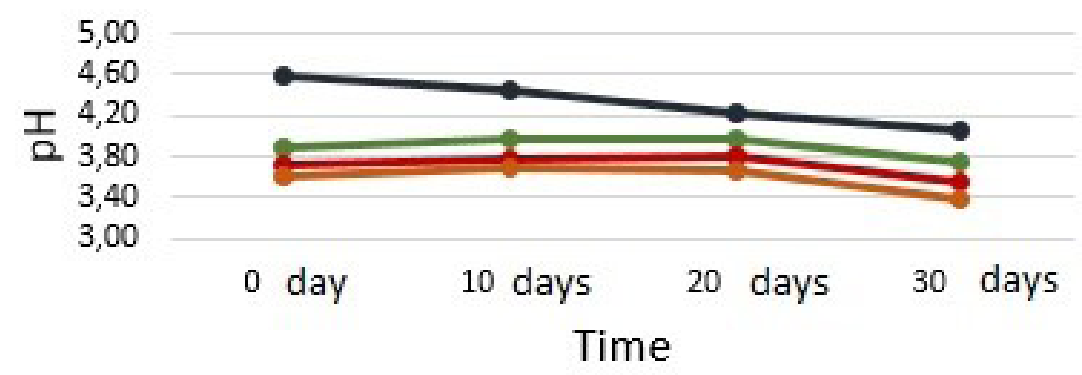

$\longrightarrow$ Natural $\longrightarrow 1,0 \% \longrightarrow 2,0 \%$

Figure 2. Average $\mathrm{pH}$ distribuition in yogurt formulations prepared with non-encapsulated extract and evaluated in different tests over time.

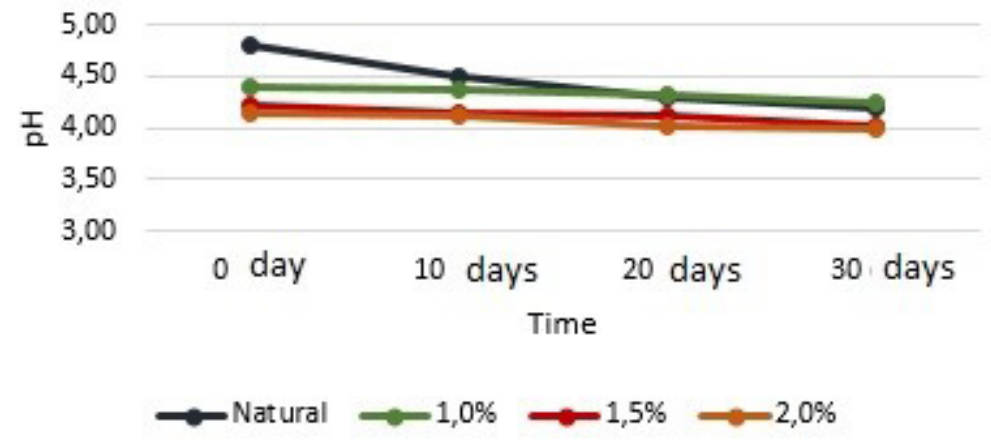

Figure 3. Average $\mathrm{pH}$ distribution in yogurt formulations prepared with encapsulated extract and evaluated in different tests over time.

It was observed that when adding encapsulated extract to the yogurt, the $\mathrm{pH}$ values obtained decreased less than in yogurt containing non-encapsulated extract. This may be due to the presence of some residue from the extracting solvent in the non-encapsulated extract and the fact that the temperature used evaporates only the solvent and not the citric acid.

It is also worth mentioning that, with the exception of the $2 \%$ formulation of yogurt prepared with non-encapsulated extract at 30 days, all formulations fall within the range recommended by MAPA Normative Instruction 46 of October 24, 2007, which establishes ideal $\mathrm{pH}$ for identity and quality of yogurt between 3.6 and 4.5 (BRAZIL, 2007).
For time zero in natural yogurt, acidity (Table 3) was $1.04 \%$ and $0.98 \%$, respectively, while for $1 \%$, $1.5 \%$ and $2 \%$ samples, values were, respectively, 1,4 , 1.7 and $2.05 \%$ (non-encapsulated extract) and 1.18, 1.29 and $1.47 \%$ (encapsulated extract), with less variation in acidity in yogurt added with encapsulated extract. It was observed that both at time zero and at the end of the 30-day trial period, natural yogurt as well as yogurts added with encapsulated extract are in agreement with physicochemical requirements of legislation, which establishes ideal acidity in lactic acid for yogurt from $0.6 \%$ to $1.5 \%$. The titratable acidity results for all yogurts increased as the extract content increased, as well as during the storage period. 
Table 3. Comparison of values obtained for acidity of yogurt added of anthocyanins from Solanum melongena L. bark in the form of non-encapsulated and encapsulated extract.

\begin{tabular}{|c|c|c|c|c|c|}
\hline Type & Test & & 10 & & \\
\hline \multirow{4}{*}{ Non-encapsulated } & Natural & $\begin{array}{c}\text { 0 days } \\
1.04 \mathrm{a} \pm 0.00\end{array}$ & $\frac{10 \text { days }}{1.04 \mathrm{a} \pm 0.01}$ & $\frac{20 \text { days }}{1.10 \mathrm{a} \pm 0.01}$ & $\begin{array}{c}30 \text { days } \\
1.11 \mathrm{a} \pm 0.05\end{array}$ \\
\hline & $1.0 \%$ & $1.49 \mathrm{a} \pm 0.01$ & $1.54 \mathrm{ab} \pm 0.02$ & $1.52 \mathrm{a} \pm 0.08$ & $1.61 \mathrm{~b} \pm 0.02$ \\
\hline & $1.5 \%$ & $1.70 \mathrm{a} \pm 0.10$ & $1.79 \mathrm{~b} \pm 0.03$ & $1.84 \mathrm{~b} \pm 0.02$ & $1.82 \mathrm{~b} \pm 0.02$ \\
\hline & $2.0 \%$ & $2.05 \mathrm{a} \pm 0.00$ & $2.06 \mathrm{a} \pm 0.11$ & $2.05 \mathrm{a} \pm 0.01$ & $2.05 \mathrm{a} \pm 0.01$ \\
\hline \multirow{4}{*}{ Encapsulated } & Natural & $0.98 \mathrm{a} \pm 0.01$ & $0.99 \mathrm{a} \pm 0.33$ & $1.03 \mathrm{a} \pm 0.01$ & $1.07 \mathrm{a} \pm 0.01$ \\
\hline & $1.0 \%$ & $1.18 \mathrm{a} \pm 0.01$ & $1.19 \mathrm{a} \pm 0.04$ & $1.41 \mathrm{~b} \pm 0.04$ & $1.21 \mathrm{a} \pm 0.02$ \\
\hline & $1.5 \%$ & $1.29 \mathrm{a} \pm 0.01$ & $1.28 \mathrm{a} \pm 0.02$ & $1.30 \mathrm{a} \pm 0.01$ & $1.33 \mathrm{a} \pm 0.01$ \\
\hline & $2.0 \%$ & $1.47 \mathrm{a} \pm 0.03$ & $1.48 \mathrm{a} \pm 0.01$ & $1.48 \mathrm{a} \pm 0.01$ & $1.49 \mathrm{a} \pm 0.00$ \\
\hline
\end{tabular}

$*$ Formulation $1 \%$ - Addition of $1 \%$ extract $* *$ Formulation $1.5 \%$ - Addition of $1.5 \%$ extract $* * *$ Formulation $2 \%-$ Addition of $2 \%$ extract. Means in rows followed by the same letters do not differ statistically from each other using the Tukey test ( $p>0.05)$. \pm Standard Deviation.

\section{Stability}

\section{Monomeric anthocyanins}

The average values obtained for anthocyanins are shown in table 4 . The anthocyanin content reduced during the storage period. The stability of compounds such as anthocyanins can be affected by the presence of oxygen, light and $\mathrm{pH}$ and, consequently, can be degraded under conditions of food processing and storage. At 30 days of experiment, anthocyanin content was no longer found in the non-encapsulated extract.

Table 4. Anthocyanins from Solanum melongena L. bark added to yogurts in the form of non-encapsulated and encapsulated extract.

\begin{tabular}{cccccc}
\hline \multirow{2}{*}{ Type } & \multirow{2}{*}{ Test } & \multicolumn{5}{c}{ Time } \\
\cline { 3 - 6 } & & 0 days & 10 days & 20 days & 30 days \\
\hline \multirow{3}{*}{ Non-encapsulated } & $1.0 \%$ & $7.51 \mathrm{a} \pm 0.50$ & $3.87 \mathrm{~b} \pm 0.13$ & $2.36 \mathrm{c} \pm 0.34$ & $0.00 \mathrm{~d}$ \\
& $1.5 \%$ & $7.57 \mathrm{a} \pm 0.21$ & $4.93 \mathrm{~b} \pm 0.82$ & $2.59 \mathrm{c} \pm 0.14$ & $0.00 \mathrm{~d}$ \\
& $2.0 \%$ & $8.01 \mathrm{a} \pm 0.01$ & $4.72 \mathrm{~b} \pm 0.55$ & $3.47 \mathrm{c} \pm 0.8$ & $0.00 \mathrm{~d}$ \\
\hline \multirow{2}{*}{ Natural Yogurt } & $1.0 \%$ & $18.00 \mathrm{a} \pm 0.20$ & $17.81 \mathrm{a} \pm 2.04$ & $17.81 \mathrm{a} \pm 0.76$ & $17.79 \mathrm{a} \pm 0.27$ \\
& $1.5 \%$ & $19.37 \mathrm{a} \pm 0.01$ & $19.00 \mathrm{ab} \pm 1.35$ & $17.37 \mathrm{ab} \pm 0.44$ & $17.22 \mathrm{~b} \pm 2.05$ \\
& $2.0 \%$ & $21.37 \mathrm{a} \pm 0.62$ & $21.59 \mathrm{a} \pm 0.38$ & $20.93 \mathrm{a} \pm 1.01$ & $19.15 \mathrm{~b} \pm 1.02$ \\
\hline
\end{tabular}

Monomeric anthocyanins $\left(100 \mathrm{~g}^{1} \mathrm{mg}\right.$ of yogurt) * Formulation $1 \%$ - Addition of $1 \%$ extract ** Formulation $1.5 \%$ - Addition of $1.5 \%$ extract *** Formulation $2 \%$ - Addition of $2 \%$ extract. Means in rows followed by the same letters do not differ statistically from each other using the Tukey test $(\mathrm{p}>0.05) . \pm$ Standard Deviation.

It was found that the anthocyanin content in the yogurt was different from levels found in the bark

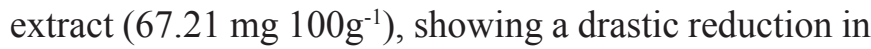
content in yogurt prepared with non-encapsulated extract during storage; while in the encapsulated extract, content remained constant, thus showing that the drying process favors the stability of anthocyanins, also presenting greater stability by reducing water activity, being able to be industrially tested.

At 20 days of storage, degradation between 56.68 and $68.85 \%$ of anthocyanins added to yogurt in the non-encapsulated form was observed. These results corroborate those found by Ścibisz et al (2019) in a study on the anthocyanin stability in yogurts added of strawberry and cherry, who reported that anthocyanin losses in comparison with freshly produced yogurts were around $11-43 \%$ after 2 weeks and $19-63 \%$ after 8 weeks of storage. Similarly, Campus et al (2017) assessed the stability of açaí pulp anthocyanins added to yogurt (AI) and fermented milk (LFA) and verified anthocyanin loss in LFA (50.4\%) and $\mathrm{AI}(40.6 \%)$, considering storage period of 28 days. The authors justified that these reductions in anthocyanin levels may be related to the incorporation of oxygen during processing and the addition of pulp or the tendency of these compounds to stabilize reactive oxygen species (CAMPUS et al, 2017). 
It was observed that encapsulated anthocyanins added to yogurt remained stable during the storage period

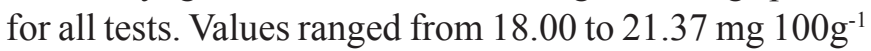
for yogurts added of $1 \%$ and $2 \%$ anthocyanin, respectively

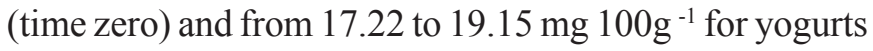
added of $1.5 \%$ and $2 \%$ anthocyanin, respectively ( 30 days of experiment).

In general, encapsulated extract had higher anthocyanin values compared to non-encapsulated extract, and test with $2.0 \%$ had the highest anthocyanin rate. Despite this, the average values did not differ statistically from the other tests.

\section{Colorimetric Analysis}

Tables 5, 6 and 7 show the average $\mathrm{L}^{*}, \mathrm{a} *$ and $\mathrm{b}$ * values obtained from colorimetric analyses of yoghurt added of non-encapsulated and encapsulated Solanum melongena L. bark extract, kept in the absence of light at temperature of $4^{\circ} \mathrm{C}$ for a period of thirty days. Through the color reading results, $\mathrm{a} *$ axis showed significant variation during the shelf life of yogurts.

Table 5. Average color distribution of $\mathrm{L} *$ parameter measured individually considering the addition of non-encapsulated and encapsulated extract.

\begin{tabular}{ccccc}
\hline \multirow{2}{*}{ Type } & Variables & $\mathbf{L}^{*}$ Parameter & L* Parameter in the non- \\
encapsulated extract & $\begin{array}{c}\text { Encapsulated } \\
\text { Non- encapsulated }\end{array}$ & $\begin{array}{c}85.38 \mathrm{a} \\
83.30 \mathrm{~b}\end{array}$ & $\begin{array}{c}\text { L Parameter in the } \\
\text { encapsulated extract }\end{array}$ \\
\hline \multirow{3}{*}{ Test } & Natural & $85.70 \mathrm{a}$ & $84.66 \mathrm{a}$ & $86.73 \mathrm{a}$ \\
& $1.0 \%$ & $84.56 \mathrm{~b}$ & $82.94 \mathrm{~b}$ & $86.18 \mathrm{a}$ \\
& $1.5 \%$ & $83.91 \mathrm{bc}$ & $83.29 \mathrm{~b}$ & $84.54 \mathrm{~b}$ \\
\multirow{2}{*}{ Time } & $2.0 \%$ & $83.19 \mathrm{c}$ & $82.30 \mathrm{~b}$ & $84.08 \mathrm{~b}$ \\
& 0 & $83.06 \mathrm{~b}$ & $82.01 \mathrm{~b}$ & $84.12 \mathrm{c}$ \\
& 10 & $83.74 \mathrm{~b}$ & $82.55 \mathrm{~b}$ & $84.93 \mathrm{bc}$ \\
& 20 & $84.98 \mathrm{a}$ & $83.90 \mathrm{a}$ & $86.06 \mathrm{ab}$ \\
\hline
\end{tabular}

* Formulation $1 \%$ - Addition of $1 \%$ extract $* *$ Formulation $1.5 \%$ - Addition of $1.5 \%$ extract *** Formulation $2 \%$ - Addition of $2 \%$ extract. L $*$ - Luminosity. Values in the same column followed by the same letters do not differ significantly by the Tukey's test at $5 \%$ probability (p $<0.05$ ).

Table 6 . Average color distribution of a * parameter measured individually considering the addition of non-encapsulated and encapsulated extract.

\begin{tabular}{|c|c|c|c|c|}
\hline \multicolumn{2}{|r|}{ Variables } & a* Parameter & \multirow[b]{2}{*}{$\begin{array}{l}\text { a* Parameter in the non- } \\
\text { encapsulated extract }\end{array}$} & \multirow[b]{2}{*}{$\begin{array}{l}\text { a* Parameter in the } \\
\text { encapsulated extract }\end{array}$} \\
\hline Type & $\begin{array}{c}\text { Encapsulated } \\
\text { Non- encapsulated }\end{array}$ & $\begin{array}{l}-6.41 \mathrm{a} \\
-2.90 \mathrm{~b}\end{array}$ & & \\
\hline \multirow{4}{*}{ Test } & Natural & $-5.40 \mathrm{~d}$ & $-3.79 d$ & $-7.02 c$ \\
\hline & $1.0 \%$ & $-4.74 \mathrm{c}$ & $-3.09 c$ & $-6.40 b$ \\
\hline & $1.5 \%$ & $-4.47 b$ & $-2.56 b$ & $-6.39 b$ \\
\hline & $2.0 \%$ & $-4.01 \mathrm{a}$ & $-2.19 a$ & $-5.83 a$ \\
\hline \multirow{4}{*}{ Time } & 0 & $-4.16 b$ & $-1.68 b$ & $-6.64 c$ \\
\hline & 10 & $-3.96 a$ & $-1.43 a$ & $-6.50 b$ \\
\hline & 20 & $-4.11 b$ & $-2.01 c$ & $-6.21 \mathrm{a}$ \\
\hline & 30 & $-6.40 c$ & $-6.50 d$ & $-6.30 \mathrm{a}$ \\
\hline
\end{tabular}

$\mathrm{a}^{*}$ Formulation $1 \%$ - Addition of $1 \%$ extract ** Formulation $1.5 \%$ - Addition of $1.5 \%$ extract *** Formulation $2 \%$ - Addition of $2 \%$ extract. a * - red intensity. Values in the same column followed by the same letters do not differ significantly by the Tukey's test at $5 \%$ probability (p $<0.05$ ). 
Table 7. Average color distribution of $b$ * parameter measured individually considering the addition of non-encapsulated and encapsulated extract.

\begin{tabular}{|c|c|c|c|c|}
\hline \multicolumn{2}{|r|}{ Variables } & \multirow{3}{*}{$\begin{array}{c}\text { b* Parameter } \\
10.65 \\
830\end{array}$} & \multirow{3}{*}{$\begin{array}{l}\text { b* Parameter in the non- } \\
\text { encapsulated extract }\end{array}$} & \multirow{3}{*}{$\begin{array}{l}\text { b* Parameter in the } \\
\text { encapsulated extract }\end{array}$} \\
\hline \multirow{2}{*}{ Type } & Encapsulated & & & \\
\hline & Non- encapsulated & & & \\
\hline \multirow{4}{*}{ Test } & Natural & $9.55 \mathrm{a}$ & $7.95 \mathrm{a}$ & $11.14 \mathrm{a}$ \\
\hline & $1.0 \%$ & $9.42 \mathrm{a}$ & $7.84 \mathrm{a}$ & $11.00 \mathrm{a}$ \\
\hline & $1.5 \%$ & $9.54 \mathrm{a}$ & $9.01 \mathrm{a}$ & $10.08 \mathrm{a}$ \\
\hline & $2.0 \%$ & $9.38 \mathrm{a}$ & $8.40 \mathrm{a}$ & $10.36 \mathrm{a}$ \\
\hline \multirow{4}{*}{ Time } & 0 & $7.33 \mathrm{~d}$ & $5.50 \mathrm{c}$ & $9.17 \mathrm{~b}$ \\
\hline & 10 & $8.18 \mathrm{c}$ & $6.40 \mathrm{c}$ & $9.97 \mathrm{~b}$ \\
\hline & 20 & $10.39 \mathrm{~b}$ & $9.11 \mathrm{~b}$ & $11.66 \mathrm{a}$ \\
\hline & 30 & $11.99 \mathrm{a}$ & $12.19 \mathrm{a}$ & $11.80 \mathrm{a}$ \\
\hline
\end{tabular}

* Formulation $1 \%$ - Addition of $1 \%$ extract $* *$ Formulation $1.5 \%$ - Addition of $1.5 \%$ extract $* * *$ Formulation $2 \%$ - Addition of $2 \%$ extract. $b *$. Yellow intensity. Values in the same column followed by the same letters do not differ significantly by the Tukey's test at $5 \%$ probability $(\mathrm{p}<0.05$ ).

Considering days 0 and 30 of evaluation of the average extract levels in the three different formulations, there was an increase in $\mathrm{L} *$ parameter, showing discoloration, which is related to the reduction of the anthocyanin content. Regarding chromaticity $\mathrm{b} *$, there was an increase in this variable for yellow, mainly in the $1 \%$ formulation. These results are consistent with studies by Ścibisz et al (2012) in probiotic blueberry yogurts, since they reported increase in $\mathrm{L}^{*}$ parameter and increase in $\mathrm{b}$ * parameter during the storage of yogurt for the possible conversion of flavylium (colored) cation into colorless or yellowish forms.
Values were close to those of natural yogurt due to the concentration of the anthocyanin extract used.

\section{Total phenolic compounds}

The amount of phenolic compounds present in yogurts added of non-encapsulated extract varied from 106.01 to $239.90 \mathrm{mg} \mathrm{GAE} 100 \mathrm{~g}^{-1}$ yogurt, whereas in yogurt added of encapsulated extract, values ranged

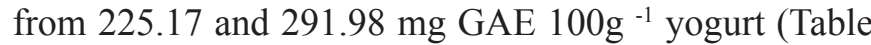
8). It was verified that the levels of phenolic compounds in encapsulated extract were higher than those in nonencapsulated extract.

Table 8. Total phenolic compounds in extracts obtained from yogurt added of Solanum melongena L. bark

\begin{tabular}{cccccc}
\hline \multirow{2}{*}{ Type } & Test & \multicolumn{5}{c}{ Time } \\
\cline { 3 - 6 } & $1.0 \%$ & $207.52 \mathrm{a} \pm 7.20$ & $203.26 \mathrm{a} \pm 2.05$ & $177.29 \mathrm{a} \pm 7.36$ & $106.01 \mathrm{~b} \pm 5.67$ \\
Non- & $1.5 \%$ & $235.60 \mathrm{a} \pm 14.87$ & $203.14 \mathrm{ab} \pm 4.27$ & $177.38 \mathrm{~b} \pm 3.02$ & $172.46 \mathrm{~b} \pm 3.37$ \\
encapsulated & $2.0 \%$ & $239.90 \mathrm{a} \pm 8.81$ & $209.00 \mathrm{ab} \pm 5.36$ & $184.57 \mathrm{~b} \pm 4.06$ & $172.32 \mathrm{~b} \pm 6.27$ \\
\hline \multirow{3}{*}{ Encapsulated } & $1.0 \%$ & $270.02 \mathrm{a} \pm 5.00$ & $263.34 \mathrm{a} \pm 8.96$ & $238.40 \mathrm{~b} \pm 3.10$ & $225.17 \mathrm{~b} \pm 2.67$ \\
& $1.5 \%$ & $286.97 \mathrm{a} \pm 5.50$ & $283.40 \mathrm{a} \pm 6.24$ & $271.55 \mathrm{a} \pm 2.37$ & $269.09 \mathrm{a} \pm 11.66$ \\
& $2.0 \%$ & $291.98 \mathrm{a} \pm 9.32$ & $286.41 \mathrm{a} \pm 10.00$ & $285.20 \mathrm{a} \pm 3.23$ & $281.97 \mathrm{a} \pm 10.86$ \\
\hline
\end{tabular}

$*$ GAE: gallic acid equivalent $* *$ Formulation $1 \%$ - Addition of $1 \%$ extract $* * *$ Formulation $1.5 \%$ - Addition of $1.5 \%$ extract **** Formulation $2 \%$ - Addition of $2 \%$ extract. Values in the same row followed by the same letters do not differ significantly by the Tukey's test at $5 \%$ probability $(\mathrm{p}<0.05) . \pm$ Standard Deviation.

Nisha et al. (2009) quantified the total phenolic content in eggplant and found values between 49.02 and $106.9891 \mathrm{mg} \mathrm{GAE} 100 \mathrm{~g}^{-1}$. These values were lower than those found in this work for yogurts added of nonencapsulated extract and those added of encapsulated extract.
In a study with pomegranate polyphenols and anthocyanins encapsulated by spray drying, Robert et al. (2010) observed that when microcapsules were added to yogurt, the stability of bioactive compounds showed behavior similar to those without encapsulation.

In the present study, this behavior was different, obtaining better levels of phenolic compounds for yogurts added of microcapsules. 
One of the determining factors for the availability of bioactive compounds is food processing. The growing demand of consumers for functional foods that help in health makes food industries increasingly concerned with the development of technological processes that enable the presence of these compounds in the final product (SÁNCHEZMORENO et al., 2009).

\section{Antioxidant activity DPPH}

The DPPH $•$ radical scavenging capacity (Table 9) decreased during the 30 days of storage, with greater antioxidant activity in the encapsulated sample $(2 \%)$ at time zero $(68.93 \%)$ and the lowest antioxidant activity at 30 days of storage. Difference in the increase of the antioxidant activity was observed when comparing encapsulated and non-encapsulated extract, where encapsulated extract showed higher antioxidant activity, which may be related to the protection of anthocyanins by the encapsulating agent.

Table 9. DPPH• radical scavenging capacity (\%) in yogurt added of anthocyanin extract from Solanum melongena L. bark in the non-encapsulated and encapsulated form.

\begin{tabular}{cccccc}
\hline \multirow{2}{*}{ Type } & \multirow{2}{*}{ Test } & \multicolumn{4}{c}{ Time } \\
\cline { 3 - 6 } & Natural & $24.76 \mathrm{O} \pm 0.76$ & $24.77 \mathrm{a} \pm 0.76$ & $22.72 \mathrm{ab} \pm 0.30$ & $19.75 \mathrm{~b} \pm 0.25$ \\
\multirow{3}{*}{ Non-encapsulated } & $1.0 \%$ & $35.70 \mathrm{a} \pm 0.20$ & $33.55 \mathrm{a} \pm 0.50$ & $28.22 \mathrm{~b} \pm 0.16$ & $22.48 \mathrm{c} \pm 0.10$ \\
& $1.5 \%$ & $49.78 \mathrm{a} \pm 0.35$ & $39.00 \mathrm{~b} \pm 1.04$ & $38.39 \mathrm{~b} \pm 0.28$ & $29.05 \mathrm{c} \pm 0.33$ \\
& $2.0 \%$ & $51.27 \mathrm{a} \pm 0.55$ & $43.07 \mathrm{~b} \pm 1.37$ & $42.27 \mathrm{~b} \pm 0.21$ & $34.85 \mathrm{c} \pm 0.23$ \\
\hline \multirow{3}{*}{ Encapsulated } & Natural & $24.77 \mathrm{a} \pm 0.10$ & $24.77 \mathrm{a} \pm 0.40$ & $22.73 \mathrm{a} \pm 0.34$ & $19.75 \mathrm{~b} \pm 0.01$ \\
& $1.0 \%$ & $53.56 \mathrm{a} \pm 0.42$ & $51.90 \mathrm{a} \pm 0.36$ & $48.90 \mathrm{~b} \pm 0.19$ & $44.16 \mathrm{c} \pm 0.51$ \\
& $1.5 \%$ & $64.64 \mathrm{a} \pm 0.02$ & $61.04 \mathrm{~b} \pm 0.20$ & $52.93 \mathrm{c} \pm 0.37$ & $47.56 \mathrm{~d} \pm 0.33$ \\
& $2.0 \%$ & $68.93 \mathrm{a} \pm 0.30$ & $55.2 \mathrm{~b} \pm 0.08$ & $51.47 \mathrm{c} \pm 0.21$ & $50.00 \mathrm{c} \pm 0.02$ \\
\hline
\end{tabular}

* Formulation $1 \%$ - Addition of $1 \%$ extract $* *$ Formulation $1.5 \%$ - Addition of $1.5 \%$ extract *** Formulation $2 \%$ - Addition of $2 \%$ extract. Means in rows followed by the same letters do not differ statistically from each other using the Tukey test ( $>0.05)$. \pm Standard Deviation.

The increase in the antioxidant activity can also be related to the use of encapsulating material, since gum arabic also has the capacity of reducing free radicals. However, according to Mirghani et al. (2018), the antioxidant activity of gum arabic with DPPH was the one with the lowest result.

Bernstein and Noreña (2015) reported that the antioxidant activity of red cabbage extract in acidified water was approximately $34.6 \%$ and, in dehydrated products, it decreased to values between 14 and $22.5 \%$, highlighting that this decrease was a consequence of high air temperatures at the atomizer outlet, which caused the degradation of compounds responsible for the antioxidant activity. Tanongkankit et al. (2015) found that the total antioxidant activity, measured by the elimination of the DPPH radical, decreased continuously during the drying process. However, this relationship was not found in the present work.

\section{Degradation Kinetics}

Table 10 shows the behavior of stored extracts over time. The degradation rate was determined and, based on $\mathrm{K}$ values obtained, half-life times $\left(\mathrm{t}_{1 / 2}\right)$ were calculated, being used as a parameter to estimate stability.

Since half-life and color retention calculations depend on the same variables (initial absorbance and final absorption) (Table 4), the half-life time would be expected to behave similarly to color retention. The half-life time of yogurt samples added of $1.5 \%$ and $2 \%$ of encapsulated anthocyanin extract was on average 178 and 187 days, respectively. This value is relatively high because the shelf life of yogurt is 45 days. The highest color retention and the longest half-life (2,310 days) were obtained for yogurt added of $1 \%$ encapsulated anthocyanin. 
Table 10. Values of degradation constants, half-life time and color retention of anthocyanins in extracts obtained from yogurt added of Solanum melongena L. bark.

\begin{tabular}{cccc}
\hline Yogurts* & Degradation constants & Half-life time $\left(\mathrm{t}_{1 / 2}\right)$ days & Color retention $(\%)$ \\
\hline Extract $1 \%$ & $\mathrm{~K}=0.0583$ & 11.89 & 31.02 \\
Extract $1.5 \%$ & $\mathrm{~K}=0.0536$ & 12.93 & 32.10 \\
Extract $2 \%$ & $\mathrm{~K}=0.0418$ & 397.92 & 43.32 \\
Powder $1 \%$ & $\mathrm{~K}=0.0003$ & 2.310 .49 & 98.83 \\
Powder $1.5 \%$ & $\mathrm{~K}=0.0039$ & 177.73 & 88.90 \\
Powder $2 \%$ & $\mathrm{~K}=0.0037$ & 187.34 & 89.61 \\
\hline
\end{tabular}

Yogurts * added of anthocyanins from Solanum melongena L. bark in the non-encapsulated and encapsulated form.

\section{Conclusion}

Anthocyanin encapsulation, although being an expensive process from the financial point of view, is indicated, since anthocyanins showed greater stability with spray-drying application.

The responses obtained for yogurt stability were superior for those added of encapsulated anthocyanin extract. All non-encapsulated extract formulations showed significant anthocyanin degradation index during the storage period, also showing loss of antioxidant action.

Encapsulated extract showed antioxidant activity superior to non-encapsulated extract, which may be related to the protection of anthocyanins by the encapsulating agent.

\section{References}

AOAC. Official methods of analysis of AOAC international. $18^{\text {th }}$ ed. Gaithersburg: AOAC International, 2005.

BERNSTEIN, A.; NOREÑA, C. P.Z. Thermodynamic sorption of red cabbage extract (Brassica oleracea L. var. capitata L. f. rubra) encapsulated by spray drying. Journal of Food Science and Technology, Campinas, v.52, n.12, p.8180-8187, 2015.

BRAND-WILLIAMS, W.; CUVELIER, M. E.; BERSET, C. Use of a free method to evaluate antioxidant activity. Lebensmittel-Wissenschaft und Technologie, London, v.28, p.25-30, 1995.

BRASIL. Ministério da Agricultura, Pecuária e Abastecimento. Instrução Normativa $n^{\circ} 46$ de 23 de outubro de 2007. Regualmento técnico de identidade e qualidade de leites fermentados. Diário Oficial da União, Brasília, seção 1, p.5, 24 de outubro de 2007.
CAMPOS, D.C.S.; NEVES, L.T.B.C.; FLACH, A.; COSTA, L.A.M.A.; SOUSA, B.O. Post-acidification and evaluation of anthocyanins stability and antioxidant activity in açai fermented milk and yogurts (Euterpe oleracea Mart.) Revista Brasileira de Fruticultura, Jaboticabal, v.39, n.5, p 1-13, 2017.

GIUSTI, M. M.; WROLSTAD, R. E. Characterization and measurement of anthocyanins by UV-visible spectroscopy. In: WROLSTAD, R.E. (Ed.). Current protocols in food analytical chemistry. New York: John Wiley \& Sons, 2001, p. 2.1-2.13.

JUNG, E-J.; BAE, M-S.; JO, E-K.; JO, Y-H.; LEE, S-C. Antioxidant activity of different parts of eggplant. Journal of Medicinal Plants Research, Sapele, v.5, n. 18, p. 4610-4615, 2011.

KATSABOXAKIS, K.; PAPANICOLAOU, D.; MELANITOU, M. Stability of pigmented orange anthocyanins in model and real food system. Italian Journal Food Science, Pinerolo, v.10, n.1, p.17-25, 1998

KAUR, C.; NAGAL, S.; NISHAD, J.; KUMAR, R.; SARIKA. Evaluating eggplant (Solanum melongena L) genotypes for bioactive properties: a chemometric approach. Food Research International, Burlington, v.60, p.205-211, 2014.

KNAPP, S.; VORONTSOVA, M. S.; PROHENS, J. Wild relatives of the eggplant (Solanum melongena L.: Solanaceae): new understanding of species names in a complex group. Plos One, San Francisco, v.8, n.2, p.1-12, 2013. 
KOBUS-CISOWSKA, J.; SZCZEPANIAK, O.; SZY MANOW S KA - POWA $\_O W S K A$, D.; PIECHOCKA, J.; SZULC, P.; DZIEDZIŃSKI, M. Antioxidant potential of various solvent extract from Morus alba fruits and its major polyphenols composition. Ciência Rural, Santa Maria, v.50, n.1, p.1-12, 2020.

MIRGHANI, M.E.S.; ELNOUR,A.A. M.; KABBASHI, N.A.; ALAM, M. Z.; MUSA, K. H.; ABDULLAH, A. Determination of antioxidante activity og gum Arabic: An axudation from two different locations. Science Asia, Bangkok, v.44, p.179-186, 2018.

MUHAMAD, I. I.; YANTI, M. M. J.; NORAZLINA, M. N.; AZNI, A. A.; ALYANI, M. P.; HONG, L. L. Advanced natural food colorant encapsulation methods: anthocyanin plant pigment. Natural and Artificial Flavoring Agents and Food Dyes, Amsterdam, n.15, p.495-526, 2018.

NIÑO-MEDINA, G.; URÍAS-ORONA, V.; MUYRANGEL, M.D.; HEREDIA, J.B. Structure and content of phenolics in eggplant (Solanum melongena)-a review. South African Journal of Botany, Pietermaritzburg, v.111, p.161-169, 2017.

NISHA, P.; ABDUL NAZAR, P.; JAYAMURTHY, P. A comparative study on antioxidant activities of different varieties of Solanum melongena. Food and Chemical Toxicology Oxford, v.47, p.2640-2644, 2009.

NODA, Y.; KNEYUKI, T.; IGARASHI, K.; MORI, A.; PACKER, L. Antioxidant activity of nasunin, an anthocyanin in eggplant peels. Toxicology, Limerick, v.148, n.2-3, p.119-123, 2000.

OTÁLORA, M.C.; CARRIAZO, J.G.; ITURRIAGA, L.; OSORIO, C.; NAZARENO, M. A. Encapsulating betalains from Opuntia ficus-indica fruits by ionic gelation: pigment chemical stability during storage of beads. Food Chemistry, London, v.202, p.373-382, 2016.

REZENDE, Y. R. R. S.; NOGUEIRA, J. P.; NARAIN, N. Microencapsulation of extracts of bioactive compounds obtained from acerola (Malpighia emarginata DC) pulp and residue by spray and freeze drying: Chemical, morphological and chemometric characterization. Food Chemistry, London, v.254, p.281-291, 2018.

RIGON, R.T.; NOREÑA, C.P.Z. Microencapsulation by spray-drying of bioactive compounds extracted from blackberry (rubus fruticosus). Journal of Food Science and Technology, Campinas, v.53, n.3, p.1515-1524, 2016.
ROBERT, P.; GORENA, T.; ROMERO, N.; SEPUlVEDA, E.; CHAVEZ, J.; SAENZ, C. Encapsulation of polyphenols and anthocyanins from pomegranate (Punica granatum) by spray drying. International Journal of Food Science and Technology, Campinas, v.45, p.1386-1394, 2010.

RODRIGUEZ-AMAYA, D. B. Natural food pigments and colorants. Science Direct, Amsterdam, v.7, p.2026, 2016.

ŚCIBISZ, I.; ZIARNO, M.; MITEK, M. Color stability of fruit yogurt during storage. Journal of Food Science and Technology, Campinas, v.56, n4, p.1997-2009, 2019.

ŚCIBISZ, I.; ZIARNO, M.; MITEKA, M.; ZAREBA, D. Effect of probiotic cultures on the stability of anthocyanins in blueberr y yoghurts. Food Science and Technology, Hoboken, v.49, n.2, p.208-212, 2012.

SILVA, G.J.F.; CONSTANT, P.B.L.; FIGUEIREDO, R.W.; MOURA, S.M. Formulação e estabilidade de corantes de antocianinas extraídas das cascas de jabuticaba (Myrciaria ssp.). Alimentos e Nutrição Araraquara, Araraquara, v.21, n.3, p.429-436, 2010.

SILVA, Q.J.; MOREIRA, A.C.C.G.; MELO, E.A.; LIMA, V.L.A.G. Compostos fenólicos e atividade antioxidantede genótipos de ciriguelas (Spondia purpurea L.). Alimentos e Nutrição Araraquara, Araraquara, v.23, n.1, p.73-80, 2012.

TADARO, A.; RAPISARDA, P.; CATALANO, A.E.; BARBAGALLO, R.N.; SPAGNA, G. Recovery of anthocyanins from eggplant peel. Food Chemistry, London, v.34, n.4, p.434- 439, 2009.

TAHER, D. SOLBERG, S.Ø.; YU-YU CHOU, P.J.; RAKHA, M.; WU, T. World vegetable center eggplant collection: origin, composition, seed dissemination and utilization in breeding. Frontiers in Plant Science, Lausanne, v.8, p. 1-12, 2017.

TANONGKANKIT, Y.; CHIEWCHAN, N.; DEVAHASTIN, S. Evolution of antioxidants in dietary fiber powder produced from white cabbage outer leaves: effects of blanching and drying methods. Journal of Food Science and Technology, Campinas, v.52, n.4, p.2280-2287, 2015.

TEIXEIRA, L.N.; STRINGHETA, P.C.; OLIVEIRA, F. A. Comparação de métodos para quantificação de antocianinas. Revista Ceres, Viçosa, MG, v.55, n.4, p.297-304, 2008. 
WALLACE, T.C.; GIUSTI, M.M. Determination of color, pigment and phenolic stability in yogurt systems colored with nonacylated anthocyanins from Berberis boliviana $\mathrm{L}$. as compared to other natural/synthetic colorants. Journal of Food Science, Chicago, v.73, n.4, p.241-248, 2008.

WETTASINGHE, M.; SHAHIDI, F. Evening primrose meal: a source of natural antioxidants and scavenger of hydrogen peroxide and oxygen-derived free radicals. Journal of Agricultural and Food Chemistry, Washington, v.47, p.1801-1812, 1999.
ZULUETA,A.; MAURIZI,A.; FRÍGOLA,A.; ESTEVE, J. M.; COLI, R.; BURINI, G. Antioxidant capacity of cow milk and deproteinized milk. International Dairy Journal, Barking, v.19, n.6-7, p.380-385, 2009. 